\title{
Effects of a combined essential fatty acid and conjugated linoleic acid abomasal infusion on metabolic and endocrine traits, including the somatotropic axis, in dairy cows
}

\author{
S. Haubold, ${ }^{1}$ C. Kröger-Koch, ${ }^{1}$ A. Tuchscherer, ${ }^{2}$ E. Kanitz, ${ }^{3}$ J. M. Weitzel, ${ }^{4}$ A. Hoeflich, ${ }^{5}$ A. Starke, ${ }^{6}$ \\ A. Tröscher, ${ }^{7}$ () H. Sauerwein, ${ }^{8} \odot$ and H. M. Hammon ${ }^{1 *}$ (b) \\ ${ }^{1}$ Institute of Nutritional Physiology "Oskar Kellner," Leibniz Institute for Farm Animal Biology (FBN), 18196 Dummerstorf, Germany \\ ${ }^{2}$ Institute of Genetics and Biometry, Leibniz Institute for Farm Animal Biology (FBN), 18196 Dummerstorf, Germany \\ ${ }^{3}$ Institute of Behavioural Physiology, Leibniz Institute for Farm Animal Biology (FBN), 18196 Dummerstorf, Germany \\ ${ }^{4}$ Institute of Reproductive Biology, Leibniz Institute for Farm Animal Biology (FBN), 18196 Dummerstorf, Germany \\ ${ }^{5}$ Institute of Genome Biology of Leibniz Institute for Farm Animal Biology (FBN), 18196 Dummerstorf, Germany \\ ${ }^{6}$ Clinic for Ruminants and Swine, Faculty of Veterinary Medicine, University of Leipzig, 04103 Leipzig, Germany \\ ${ }^{7}$ BASF SE, 68623 Lampertheim, Germany \\ ${ }^{8}$ Institute of Animal Science, Physiology and Hygiene Unit, University of Bonn, 53115 Bonn, Germany
}

\section{ABSTRACT}

The objective of this study was to test the effects of essential fatty acids (EFA), particularly o-linolenic acid (ALA), and conjugated linoleic acid (CLA) supplementation on metabolic and endocrine traits related to energy metabolism, including the somatotropic axis, in mid-lactation dairy cows. Four cows (126 $\pm 4 \mathrm{~d}$ in milk) were used in a dose-escalation study design and were abomasally infused with coconut oil (CTRL; $38.3 \mathrm{~g} / \mathrm{d}$; providing saturated fatty acids), linseed and safflower oils $(\mathrm{EFA} ; 39.1$ and $1.6 \mathrm{~g} / \mathrm{d}$; n-6:n-3 FA ratio $=1: 3$ ), Lutalin (CLA; cis-9,trans-11 and trans-10,cis-12 CLA, $4.6 \mathrm{~g} / \mathrm{d}$ of each), or EFA and CLA (EFA+CLA) for 6 wk. The initial dosage was doubled twice after $2 \mathrm{wk}$, resulting in 3 dosages (dosages 1, 2, and 3). Each cow received each fat treatment at different times. Cows were fed with a corn silage-based total mixed ration providing a low-fat content and a high n-6:n-3 fatty acid ratio. Plasma concentrations of metabolites and hormones (insulin-like growth factor-binding proteins only on wk 0 and 6 ) were analyzed at wk $0,2,4$, and 6 of each treatment period. Liver biopsies were taken before starting the trial and at wk 6 of each treatment period to measure hepatic mRNA abundance of genes linked to glucose, cholesterol and lipid metabolism, and the somatotropic axis. The changes in the milk and blood fatty acid patterns and lactation performance of these cows have already been published in a companion paper. The plasma concentra-

Received March 20, 2020.

Accepted July 17, 2020.

*Corresponding author: hammon@fbn-dummerstorf.de tion of total cholesterol increased with dosage in all groups, except CLA, reaching the highest levels in EFA+CLA and CTRL compared with CLA. The highdensity lipoprotein cholesterol plasma concentration increased in CTRL and was higher than that in EFA and CLA, whereas the concentration of low-density lipoprotein cholesterol increased in a dose-dependent manner in EFA and EFA+CLA, and was higher than that in CLA. Hepatic mRNA expression of 3-hydroxy3-methyl-glutaryl-CoA synthase 1 was upregulated in all groups but was highest in EFA+CLA. Expression of sterol regulatory element-binding factor 1 tended to be lowest due to EFA treatment, whereas expression of long chain acyl-CoA-synthetase was lower in EFA than in CTRL. Hepatic mRNA expression of GHR1A tended to be higher in EFA+CLA than in CTRL. The plasma concentration of insulin-like growth factor I increased in CLA, and the plasma IGFBP-2 concentration was lower in EFA+CLA than in CTRL at wk 6. The plasma concentration of adiponectin decreased in EFA+CLA up to dosage 2. Plasma concentrations of albumin and urea were lower in CLA than in CTRL throughout the experimental period. Supplementation with EFA and CLA affected cholesterol and lipid metabolism and their regulation differently, indicating distinct stimulation after the combined EFA and CLA treatment. The decreased IGFBP-2 plasma concentration and upregulated hepatic mRNA abundance of GHR1A in EFA+CLA-supplemented cows indicated the beneficial effect of the combined EFA and CLA treatment on the somatotropic axis in mid-lactation dairy cows. Moreover, supplementation with CLA might affect protein metabolism in dairy cows.

Key words: dairy cow, essential fatty acids, conjugated linoleic acid, energy metabolism, somatotropic axis 


\section{INTRODUCTION}

Essential fatty acids (EFA), namely $\alpha$-linolenic acid (ALA) and linoleic acid (LA), are important components for the functioning of mammalian organisms, which has been well described in previous studies ( $\mathrm{Si}$ mopoulos, 2002; Lands, 2014). Mammals are not able to synthesize ALA and LA; therefore, they must be obtained from the diet (Spector and Kim, 2015), which is also true for ruminants (Palmquist, 2010). These fatty acids are incorporated into phospholipids of cell membranes, and their metabolites interact as precursors for prostaglandin synthesis as well as mediate reproductive functions and the acute phase response (Mattos et al., 2000; Wathes et al., 2007; Sordillo et al., 2009). Additionally, ruminal synthesis of CLA isomers depends on LA and ALA intake (Bauman et al., 2000; Chilliard et al., 2001; Shingfield et al., 2010). Some CLA isomers have gained attention for their health-promoting effects in mammals (Nagao and Yanagita, 2005; Shokryzadan et al., 2017), but metabolic effects in dairy cows (e.g., milk fat-reducing and glucose-saving effects) have also been reported in previous studies (Bauman et al., 2011; Hötger et al., 2013; Benninghoff et al., 2015). Furthermore, some studies observed the effects of CLA on the somatotropic axis (Castañeda-Gutiérrez et al., 2007; Csillik et al., 2017), describing the interactions of growth hormone, IGF-I, and their binding proteins (IGFBP). The somatotropic axis assumes a key role in the control of homeorhetic processes related to milk production (Bauman, 2000; Renaville et al., 2002). However, most studies on the somatotropic axis in dairy cows were carried out during the transition period, and knowledge about the metabolic and endocrine effects of combined EFA and CLA treatment in cows within established lactation is rather scarce.

Because diets for dairy cows have changed over the last few decades (with less pasture but more TMR based on corn silage as the main forage source provided; Khan et al., 2015), the fatty acid (FA) supply and the intake of EFA have changed, with a decrease in the intake of ALA. Grass in pasture contains high amounts of ALA (Chilliard et al., 2001; Ferlay et al., 2006; Khiaosa-Ard et al., 2015), and rumen digestion of PUFA produces large amounts of CLA when cows are on pasture (Kelly et al., 1998; Ferlay et al., 2006; Lahlou et al., 2014). The importance of n-3 FA in dairy production has been previously reviewed (Palmquist, 2010; Moallem, 2018). In contrast, corn silage is rich in LA, but rations with corn silage as the main forage source often contain less fat (Chilliard et al., 2001; Khan et al., 2015). Therefore, the forage type strongly affects the EFA and n-6:n-3 ratio, as well as the CLA status of dairy cows (Chilliard et al., 2001; Shingfield et al., 2010; Khan et al., 2015).
Altering the $n-6: n-3$ ratio via changes in the EFA supply not only influences lactation performance in dairy cows (Silvestre et al., 2011; Greco et al., 2015), but also affects metabolic regulation in cattle (Pegolo et al., 2016). However, relatively little is known about whether there are synergistic or opposing effects of combined EFA and CLA treatment on different metabolic traits and endocrine systems, such as the somatotropic axis, in mid-lactation dairy cows.

Thus, the aim of the present study was to investigate the immediate effects of increasing EFA and CLA dosages on plasma metabolites and endocrine changes, with a special focus on lipid metabolism and the somatotropic axis in mid-lactation dairy cows. The treatments focused on the supply of FA that provide a reduced $n$ -6:n-3 EFA ratio and CLA occurring at normal levels in cows fed fresh grass or that are kept on pasture (Kelly et al., 1998; Ferlay et al., 2006; Lahlou et al., 2014). Cows were supplied with linseed and safflower oil in a ratio of 19.5:1 (EFA; providing an n-6:n-3 FA ratio of $1: 3$ in the supplement mixture), CLA (cis-9,trans-11 and trans-10,cis-12 CLA in equal amounts), or a combination of both in increasing amounts, comparable to a pasture-based feeding system (Kelly et al., 1998; Ferlay et al., 2006). To avoid rumen degradation of the supplemented FA, all FA were administered as oils by abomasal infusion. We hypothesized that the immediate effects on energy metabolism and the somatotropic axis would be most evident during combined EFA and CLA supplementation in mid-lactation dairy cows.

\section{MATERIALS AND METHODS}

\section{Animal Husbandry, Diet, and FA Supplementation}

The experimental procedures in the current study were performed in strict accordance with the German Animal Welfare Act and were approved by the relevant Department for Animal Welfare Affairs of the state of Mecklenburg-Vorpommern (Landesamt für Landwirtschaft, Lebensmittelsicherheit und Fischerei Mecklenburg-Vorpommern, Germany; LALLF M-V/ TSD/7227.3-1-061/14).

The study design, preparation of the cows, and first results on changes in the FA pattern in blood plasma and milk and on the performance of these cows (DMI, milk yield, milk composition, body condition, energy balance) were recently published in a companion paper (Haubold et al., 2020). Four German Holstein cows with an average BW of $578 \pm 14 \mathrm{~kg}$ were purchased from a local farm (Adap Rinderzucht GmbH, Ahrenshagen, Germany) 3 mo before starting the trial and kept in the freestall barn of the experimental cattle facility at the Leibniz Institute for Farm Animal Biology (FBN, 
Dummerstorf, Germany). The cows were immediately adapted to the experimental diet, which was offered ad libitum. The diet contained $433 \mathrm{~g} / \mathrm{kg}$ of $\mathrm{DM}$ of corn silage and $115 \mathrm{~g} / \mathrm{kg}$ of DM of straw as forage sources, as well as $124 \mathrm{~g} / \mathrm{kg}$ of DM of extracted soybean meal, $207 \mathrm{~g} / \mathrm{kg}$ of DM of dried sugar beet pulp, and $101 \mathrm{~g} /$ $\mathrm{kg}$ of DM of rye grains. The chemical composition was 149,24 , and $361 \mathrm{~g} / \mathrm{kg}$ of DM for CP, crude fat, and NDF, respectively. The energy content was $6.7 \mathrm{MJ} /$ $\mathrm{kg}$ of $\mathrm{DM} \mathrm{NE} \mathrm{L}_{\mathrm{L}}$. The diet was originally published in a companion paper of this study (Haubold et al., 2020) and is presented in Supplemental Table S1 (https://doi .org $/ 10.3168 /$ jds.2020-18569). The diet was composed to deliver a low-fat content and high n-6:n-3 EFA ratio (Haubold et al., 2020; Supplemental Table S2, https:// doi.org/10.3168/jds.2020-18569). The chemical composition of the diet was calculated in accordance with the recommendations of the German Society of Nutritional Physiology (GfE, 2001; 2008). The cows had free access to water, and the individual feed intake was recorded daily (Haubold et al., 2020).

Cows were arranged in $4 \times 4$ Latin square with a dose escalation within each treatment period. The control cows (CTRL) received coconut oil (Sanct Bernhard, Bad Ditzenbach, Germany), which is composed predominantly of SFA (contains mainly lauric acid, myristic acid, caprylic acid, and capric acid). Cows in the EFA treatment received a mix of linseed oil (Derby, Derby
Spezialfutter GmbH, Münster, Germany) and some safflower oil (Gefro, GC Memmingen/Allgäu, Germany) to provide an n-6:n-3 ratio of 1:3 (linseed:safflower oil ratio $=19.5: 1)$. Cows in the CLA treatment received Lutalin (BASF, Ludwigshafen, Germany), providing cis-9,trans-11 CLA and trans-10,cis-12 CLA. Cows in the combined treatment $(\mathbf{E F A}+\mathbf{C L A})$ received a combination of EFA and CLA. The amounts of the daily infused oils are shown in Table 1, and the FA compositions of the single oils and of the complete lipid supplements are presented in Supplemental Tables S3 and S4 (https://doi.org/10.3168/jds.2020-18569). Each cow received each fat treatment at different times; each supplementation period lasted for $6 \mathrm{wk}$ in total. During this time, cows received lipid supplementation in 3 successively increasing dosages, each for $2 \mathrm{wk}$, resulting in 3 dosages of each treatment (dosages 1,2 , and 3 ). There was a 3 -wk washout period (no supplementation) between each experimental period. The basal doses of FA application were based on previous studies (Benson et al., 2001; Pires et al., 2008; Hötger et al., 2013).

\section{Blood Sampling and Analyses}

Blood samples were collected by venipuncture of the jugular vein as recently described (Haubold et al., 2020). Plasma metabolites were analyzed in blood samples containing sodium fluoride $(2-4 \mathrm{mg} / \mathrm{mL})$ and

Table 1. Amounts of daily abomasally infused supplements ${ }^{1,2}$

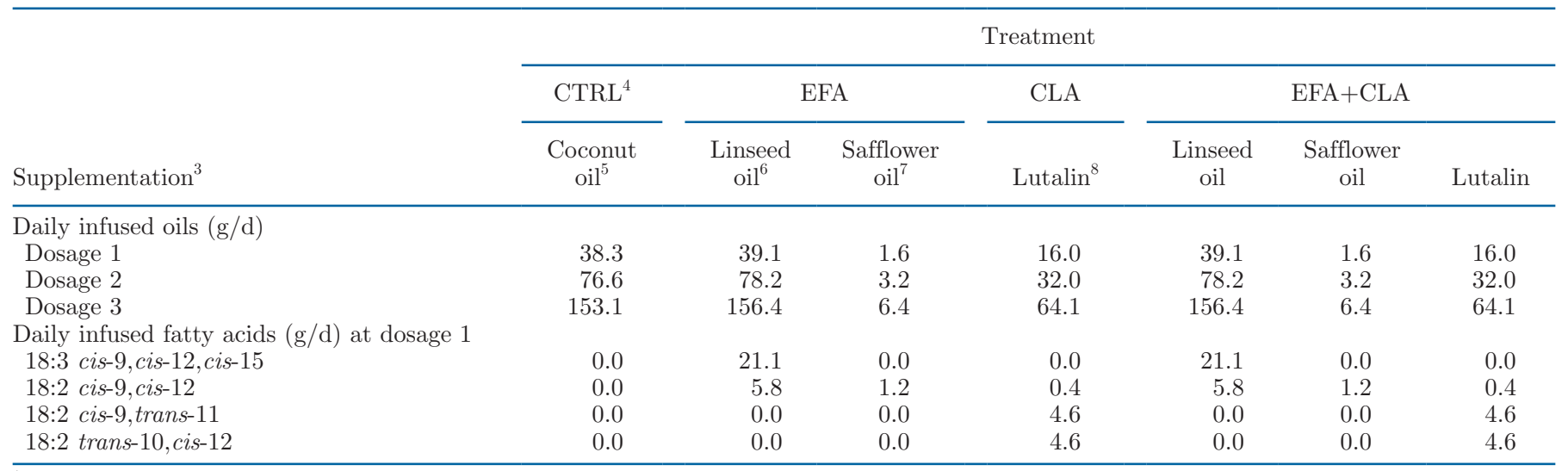

${ }^{1}$ This table was first published by Haubold et al. (2020).

${ }^{2}$ Cows were supplemented daily with coconut oil (CTRL), linseed and safflower oil (EFA), Lutalin (CLA, cis-9, trans-11 and trans-10, cis-12), or both EFA and CLA (EFA+CLA).

${ }^{3}$ The initial dosage 1 was doubled twice for 2 wk to dosages 2 and 3 , resulting in a 6 -wk treatment period that was followed by a 3 -wk washout period.

${ }^{4}$ Addition of vitamin E (0.03, 0.06, or $0.12 \mathrm{~g} / \mathrm{d}$ for dosages 1, 2, and 3, respectively), Covitol 1360 (BASF, Ludwigshafen, Germany), to compensate for vitamin E in linseed oil (0.07\%) and safflower oil (0.035\%; Supplemental Table S3, https://doi.org/10.3168/jds.2020-18569).

${ }^{5}$ Sanct Bernhard, Bad Ditzenbach, Germany.

${ }^{6}$ DERBY, Derby Spezialfutter GmbH, Münster, Germany.

${ }^{7}$ GEFRO, Memmingen/Allgäu, Germany.

${ }^{8}$ BASF, Ludwigshafen, Germany. 
potassium oxalate $(1-3 \mathrm{mg} / \mathrm{mL})$ as anticoagulants using an automatic spectrophotometer (ABX Pentra 400; Horiba ABX, Montpellier, France) and the following kits: glucose (A11A01667), lactate (A11A01721), albumin (A11A01664), high-density lipoprotein cholesterol (HDL-C; A11A01636), low-density lipoprotein cholesterol (LDL-C; A11A01638), and triacylglycerides (A11A01640) from HORIBA ABX (Montpellier, France); total protein (553-412) and cholesterol (553-127) from mti-diagnostics (Idstein, Germany); BHB from Randox (Ranbut RB 1008, Crumlin, UK); urea (LT-UR 0010) and total bilirubin (LT-BR 0100) from Labor+Technik (E. Lehmann, Berlin, Germany); and nonesterified fatty acids (NEFA; 434-91795, 436-91995) from WAKO Chemicals (Neuss, Germany).

Plasma concentrations of insulin (\#RIA-1257) and glucagon (\#RIA-1258) were detected in plasma samples containing K3-EDTA by RIA using kits from DRG Instruments (Marburg, Germany), which were adapted to bovine plasma as described by Hammon et al. (2009). The plasma cortisol concentration was analyzed in plasma samples containing K3-EDTA as an anticoagulant. After extraction with diethyl ether, a commercially available ELISA kit (\#EIA-1887; DRG Instruments) was used according to the instructions of the manufacturer (Weber et al., 2013). The crossreactivities of the used antibody to corticosterone and progesterone were $45 \%$ and $9 \%$, respectively, and those to any further competing plasma steroids were lower than $2 \%$. The assay was validated for use with bovine plasma. The test sensitivity was $3.5 \mathrm{ng} / \mathrm{mL}$, and the intra- and interassay coefficients of variation were $4.7 \%$ and $12.7 \%$, respectively. The plasma concentration of IGF-I was measured by an ELISA adapted from Daxenberger et al. (1998) using an anti-human IGF-I polyclonal antiserum (GroPep, Adelaide, Australia) that showed $100 \%$ cross-reactivity to bovine IGF-I (Frieten et al., 2018). The intra- and interassay variations were $6.4 \%$ and $9.1 \%$, respectively. Plasma concentrations of IGFBP were analyzed by quantitative Western ligand blot analysis as previously described (Laeger et al., 2014; Wirthgen et al., 2016) using plasma samples containing K3-EDTA. Plasma concentrations of leptin and adiponectin were analyzed in EDTA-plasma samples by using an ELISA established by Sauerwein et al. (2004) and Mielenz et al. (2013), and modified by Kesser et al. (2015). The intra- and interassay coefficients of variation were $3 \%$ and $7.8 \%$, respectively, for leptin and $4.9 \%$ and $13.7 \%$, respectively, for adiponectin.

\section{Liver Tissue Sampling and Analyses}

Liver samples were taken by needle biopsy as recently described before the start of the trial and after every 6-wk supplementation period (Weber et al., 2013; Haubold et al., 2020). The collected samples were immediately frozen in liquid nitrogen and stored at $-80^{\circ} \mathrm{C}$ until analysis. Liver tissue was crushed to a fine powder using a mortar and pestle under liquid nitrogen for all analyses. The glycogen content was measured using a commercial photometric kit based on amyloglucosidasecatalyzed release of glucose (10207748035, Boehringer Mannheim/R-Biopharm AG, Darmstadt, Germany). To determine the DM content of the liver, tissue samples $(50 \mathrm{mg})$ were dried for $3 \mathrm{~h}$ at $105^{\circ} \mathrm{C}$.

Tissue preparation for mRNA quantification was recently described by Weber et al. (2017) and Haubold et al. (2020). Briefly, total RNA was extracted from nitrogen-frozen, homogenized powdered tissue of the liver with TRIzol Reagent (Life Technologies, Darmstadt, Germany). The integrity and quality of the total RNA was confirmed by gel electrophoresis and by measuring the RNA integrity number value with a bioanalyzer using the Agilent RNA 6000 Nano Kit (Agilent Bioanalyzer 2100, Hamburg, Germany). The mean RNA integrity number for the liver tissue was $7.06 \pm 0.19$. The quantity and quality of the total RNA was also determined by measuring the optical density via a spectrophotometer (NanoPhotometer; Implen GmbH, Munich, Germany) at 260:280. For cDNA synthesis, $750 \mathrm{ng}$ of RNA was reverse-transcribed with 200 U of RevertAid Reverse Transcriptase (Thermo Fisher Scientific, Schwerte, Germany) and 250 pmol of random hexamer primer (metabion international AG, Planegg-Steinkirchen, Germany). The cDNA was diluted 1:4 with diethyl dicarbonate water, and aliquots were stored at $-80^{\circ} \mathrm{C}$.

Quantification of the relative mRNA abundance of selected genes was conducted as described in a previous article (Saremi et al., 2012). We used EMD and POLR2A as reference genes. The primer sequences, accession numbers, and PCR conditions for the target genes are listed in Supplemental Table S5 (https://doi .org/10.3168/jds.2020-18569). The selected target genes related to glucose and lipid metabolism were $P C C A$, PC, PCK1, PCK2, G6PC, INSR, NR3C1, CPT1A, ASCL1, ACADVL, DGAT, APOB, APOA1, MTTP, SREBF1, PPARA, PPARG, HMGCS1, HMGCS2, ADIPOR1, and ADIPOR2. Additionally, genes related to the somatotropic axis, such as IGF1, IGF1R, GHR1A, $I G F B P 2$, and $I G F B P 3$, were targeted. Primer products were verified by sequencing using the BigDye Terminator v1.1 Cycle Sequencing Kit and an ABI 3130 Genetic Analyzer (Life Technologies, Carlsbad, CA). Real-time PCR was conducted with the use of a LightCycler (Roche Molecular Biochemicals, Mannheim, Germany); SYBR Green I was used as the fluorescent dye. Melting curve analysis and agarose gel electrophoresis were used 
for verification of PCR products. The quantification cycle values and amplification efficiencies obtained by using LinRegPCR version 2013.0 (Ruijter et al., 2013) were imported into qBASE+ version 2.6.1 (Biogazelle, Gent, Belgium) for all subsequent calculations and quality controls. For normalization, the geometric mean of the reference gene abundance was used. Data are presented as the ratios of the copy numbers of the gene of interest to the geometric mean of the reference gene abundances.

\section{Statistical Analysis}

All statistical analyses were conducted with the SAS System for Windows, release 9.4 (SAS Institute Inc., Chicago, IL). Data were analyzed by repeated measures ANOVA using the MIXED procedure. The model for metabolic and endocrine data in blood plasma contained the treatment (levels: CTRL, EFA, CLA, EFA+CLA), dosage (levels: 0, 1, 2, 3), and the interaction treatment $\times$ dosage as fixed factors, whereas weeks in milk served as a covariate. For the data of relative mRNA expression in liver tissue, the model included only the fixed factor treatment [levels: NO (no supplementation), CTRL, EFA, CLA, EFA+CLA], and weeks in milk was used as a covariate. For both models, cow was included as random effect, and repeated measures on the same cow were considered using the REPEATED statement of the MIXED procedure and an unstructured type of block diagonal residual covariance matrix. The denominator degrees of freedom for testing the fixed effects in the repeated measures were computed by the DDFM option "SAT." The results are presented as least squares means $(\mathbf{L S M}) \pm$ standard error. Pairwise differences in LSM were tested using the Tukey-Kramer procedure. The SLICE statement of the MIXED procedure was used to perform partitioned analyses of the LSM for 2-way interactions. Differences with $P<0.05$ were considered significant.

\section{RESULTS}

As shown in the first paper of this study (Haubold et al., 2020), supplementation with EFA alone or in combination with CLA led to an increase in the ALA and n-3 FA in milk fat and blood plasma and decreased the n-6:n-3 FA status in the cows. The previous results confirmed that CLA without or together with EFA supplementation promoted milk fat depression, but a slight improvement in the energy balance was observed only in cows treated with CLA alone. Milk fat depression by CLA treatment was primarily caused by inhibition of de novo FA synthesis. There was no consistent effect of CLA alone or in combination with EFA on DMI and milk yield, but the milk protein concentration decreased in CLA-treated cows with or without EFA treatment (Haubold et al., 2020).

\section{Changes in Metabolites and Hormones in Plasma}

The plasma concentration of total cholesterol was affected by treatment $(P<0.05)$ and dosage $(P<0.001)$, and increased $(P<0.05)$ in all groups (except in CLA) with dosage. Plasma total cholesterol was lower in CLA than in EFA+CLA $(P<0.001)$ at dosages 2 and 3, and was lower in CLA than in CTRL $(P<0.01)$ at dosage 3 (Figure 1A; Supplemental Table S6, https:/ /doi.org/10.3168/jds.2020-18569). The HDL-C plasma concentration was affected by both treatment and dosage $(P<0.05)$, and increased $(P<0.01)$ in CTRL in a dose-dependent manner. Plasma HDL-C was higher in CTRL than in EFA $(P<0.05)$ and CLA $(P<0.01)$ at dosage 3 , and was lower $(P<0.01)$ in CLA than in EFA+CLA throughout the experimental period (Figure 1B; Supplemental Table S6). The plasma concentration of LDL-C was also affected by treatment $(P<0.05)$ and dosage $(P<0.001)$, and increased dose-dependently in EFA $(P<0.01)$ and EFA+CLA $(P<0.001)$. Plasma LDL-C was higher $(P<0.05)$ in EFA + CLA than in CLA throughout the experimental period and at dosages 2 and 3, and was higher or tended to be higher in EFA + CLA than in EFA $(P<0.05)$ and in CTRL $(P<$ 0.1 ) throughout the entire experimental period (Figure 1C). The plasma triglyceride concentration was not affected by treatment or dosage (Figure 1D).

The plasma concentration of BHB was affected by dosage $(P<0.05)$, but BHB as well as the plasma glucose and NEFA concentrations showed no differences among groups or individual dosage effects (Table 2 ; Figure 2A, B). The plasma concentrations of lactate and total bilirubin showed no treatment or dosage effects (Table 2). The plasma albumin concentration was influenced by treatment $(P<0.05)$ and was higher $(P$ $<0.05)$ in CTRL than in CLA at dosage 3 , whereas the total plasma protein concentration was not affected by dosage or treatment (Table 2). The plasma concentration of urea was lower $(P<0.05)$ in CLA-treated cows than in CTRL cows over the entire experimental period (Table 2).

The plasma concentration of adiponectin was influenced by treatment $(P<0.05)$ and dosage $(P<0.01)$; it was higher in EFA+CLA than in CLA $(P<0.01)$ at washout, and decreased $(P<0.01)$ in EFA+CLA in a dose-dependent manner from washout to dosage 2 (Table 3). The plasma concentration of leptin was not affected by treatment or dosage (Table 3). Plasma 
A

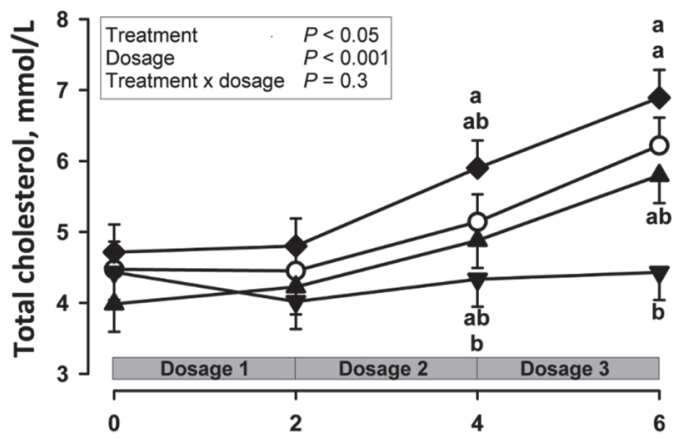

C

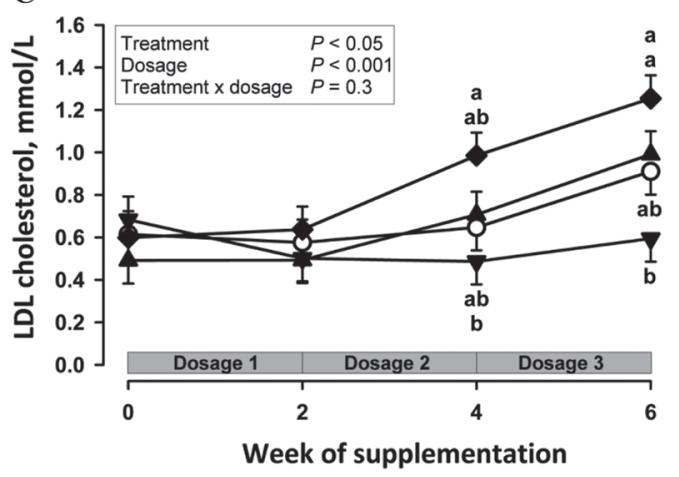

B

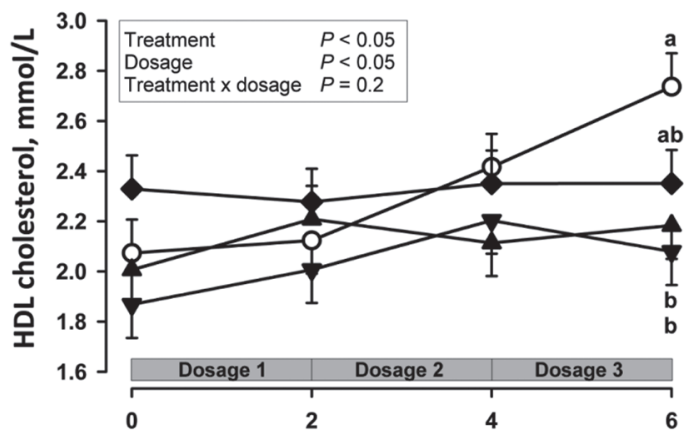

D

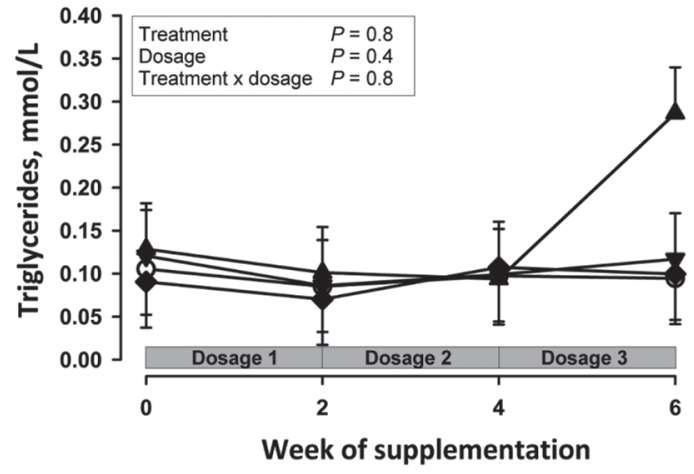

Figure 1. (A) Plasma concentrations of total cholesterol, (B) high-density lipoprotein cholesterol (HDL cholesterol), (C) low-density lipoprotein cholesterol (LDL cholesterol), and (D) triglycerides in cows fed a corn silage-based diet and abomasally treated with coconut oil $(\bigcirc \mathrm{CTRL})$, linseed and safflower oils ( $\mathbf{E F A}$ ), Lutalin ( $\mathbf{\nabla}$ CLA cis-9, trans-11 and trans-10,cis-12), or ( $)$ EFA+CLA at dosages 1, 2, and 3 (wk 2, 4, and 6 , respectively). The initial dosage was doubled twice for $2 \mathrm{wk}$, resulting in a 6 -wk treatment period with 3 dosages $(1,2,3)$ followed by a 3 -wk washout period. Values are the LSM $\pm \mathrm{SE}, \mathrm{n}=4$ per group; means with different letters $(\mathrm{a}, \mathrm{b}) \operatorname{differ}(P<0.05)$.

concentration of insulin increased $(P<0.05)$ in a dosedependent manner in CTRL from washout to dosage 2 (Figure 2C; Supplemental Table S7, https://doi.org/10 .3168/jds.2020-18569). Plasma concentrations of cortisol and glucagon were not affected by treatment or dosage (Table 3). The plasma concentration of IGF-I was affected by treatment $(P<0.01)$, and was lower $(P<$ 0.05) in CLA than in CTRL and EFA at washout (only CTRL) and at dosage 1, whereas at dosages 2 and 3 , all groups had the same IGF-I concentration (Figure 2D; Supplemental Table S7). Considering the whole experimental period, regardless of the dosage, CLA had lower $(P<0.01)$ IGF-I plasma concentrations than CTRL and EFA, while EFA+CLA tended $(P=0.08)$ to have lower concentrations than CTRL. Plasma IGF-I tended to increase $(P=0.1)$ in CLA from dosages 1 to 3 . The plasma IGFBP-2 concentration was lower $(P<0.05)$ in EFA+CLA than in CTRL $(P<0.001$; Figure 2E; Supplemental Table S7), whereas the plasma concentration of IGFBP-3, the IGFBP-3:IGFBP-2 ratio, and the concentration of IGFBP-4 showed no treatment or dosage effect (Figure 2F; Table 3).

\section{Hepatic DM, Glycogen, and mRNA Expression of Genes Related to Glucose and Lipid Metabolism and to the Somatotropic Axis}

The DM content of liver tissue was influenced by treatment $(P<0.05)$, and was higher $(P<0.05)$ in CTRL $(361 \pm 13.3 \mathrm{mg} / \mathrm{g})$, EFA $(383 \pm 13.3 \mathrm{mg} / \mathrm{g})$, and EFA+CLA $(384 \pm 13.3 \mathrm{mg} / \mathrm{g})$ than before the start of the treatments $(295 \pm 17.0 \mathrm{mg} / \mathrm{g}$ of liver). The hepatic glycogen concentration was $6.7 \pm 0.9 \%$ of DM and did not differ among groups.

The relative mRNA abundance of $N R 3 C 1$ was affected by treatment $(P<0.01)$; it was higher in CLA $(P<0.05)$ and EFA+CLA $(P<0.01)$ than in NO, and tended to be higher in EFA+CLA $(P<0.07)$ than in EFA (Table 4). The abundance of $A S C L 1$ mRNA was affected by treatment $(P<0.05)$; it was lower $(P<0.05)$ in EFA than in CTRL and NO, whereas the abundance of $C P T 1 A$ mRNA tended to be lower in CLA than in NO $(P<0.1$; Table 4$)$. The relative mRNA expression of $S R E B F 1$ was affected by treatment; it was lowest in EFA and EFA+CLA $(P<0.05)$, 
and tended to be lower in EFA than in CTRL $(P=$ 0.1 ; Table 4). Hepatic gene expression of HMGCS1 was affected by treatment $(P<0.05)$; it was higher in EFA +CLA compared with NO $(P<0.05)$, and tended to be higher in EFA+CLA compared with EFA $(P<$ $0.1)$ and in CTRL compared with NO $(P<0.1$; Table $4)$. There was a trend indicating a treatment effect $(P$ $=0.069)$ for the abundance of GHR1A mRNA, which tended to be higher in EFA+CLA than in CTRL ( $P$ $<0.1)$ and NO $(P<0.1$; Table 4$)$. Hepatic mRNA expression of INSR was influenced by treatment $(P<$ $0.05)$; it was lower $(P<0.05)$ in EFA and in CLA than in NO, and tended $(P<0.1)$ to be lower in CTRL than in NO (Table 4).

\section{DISCUSSION}

\section{Effects of FA Supplementation on Cholesterol Metabolism and Lipoproteins}

In humans, lauric acid leads to an increase in total cholesterol plasma concentration, particularly by increasing LDL-C, which carries most of the cholesterol in blood plasma in monogastric species (Nicolosi, 1997; Fernandez and West, 2005). In addition, lauric acid increases total cholesterol in blood plasma by stimulating
HDL-C in humans (Mensink et al., 2003). An increase in total cholesterol, as well as LDL-C and HDL-C, was also observed in CTRL cows in the present study with increasing doses of coconut oil, which contains lauric acid as the main FA. Other FA, such as LA, were also elevated in CTRL cows (Haubold et al., 2020) and may have contributed to the elevated HDL-C plasma concentration in CTRL because PUFA stimulate the HDL plasma concentration, and LA is primarily transported in the cholesterol ester and phospholipid fraction of HDL (Hocquette and Bauchart, 1999; Vargas-Bello-Pérez et al., 2016). However, the plasma LA concentration was also elevated in EFA+CLA-treated cows (Haubold et al., 2020), but there was no dose-dependent increase in the HDL-C plasma concentration in EFA+CLA-treated cows.

Rumen-protected PUFA significantly increases the total plasma cholesterol in cattle (Bitman et al., 1973; Ashes et al., 1982; Scislowski et al., 2004), and this increase is consistent with the present findings in EFAand EFA+CLA-treated cows. In addition, the concentrations of LDL-C increased in EFA and in EFA+CLA, consistent with the results of Palmquist (1976) and Bitman et al. (1973), who reported an increase in LDL induced by the rumen-protected PUFA supply in cattle. In contrast to the result in cattle, treatment with PUFA

Table 2. Effects of abomasal treatments on plasma concentrations of BHB, lactate, total bilirubin, total protein, albumin, and urea ${ }^{1}$

\begin{tabular}{|c|c|c|c|c|c|c|c|c|c|}
\hline \multirow[b]{2}{*}{ Variable } & \multirow[b]{2}{*}{ Period $^{2}$} & \multicolumn{4}{|c|}{ Treatment $^{3}$} & \multirow[b]{2}{*}{$\mathrm{SE}$} & \multicolumn{3}{|c|}{$P$-value } \\
\hline & & CTRL & EFA & CLA & $\mathrm{EFA}+\mathrm{CLA}$ & & Treatment & Dosage & $\begin{array}{c}\text { Treatment } \\
\times \text { dosage }\end{array}$ \\
\hline \multirow[t]{4}{*}{$\mathrm{BHB}, \mathrm{mmol} / \mathrm{L}$} & Washout & 0.24 & 0.23 & 0.35 & 0.32 & 0.07 & 0.18 & 0.05 & 0.43 \\
\hline & Dosage 1 & 0.27 & 0.27 & 0.27 & 0.20 & 0.07 & & & \\
\hline & Dosage 2 & 0.46 & 0.33 & 0.33 & 0.37 & 0.07 & & & \\
\hline & Dosage 3 & 0.44 & 0.29 & 0.24 & 0.41 & 0.07 & & & \\
\hline \multirow[t]{2}{*}{ Lactate, $\mathrm{mmol} / \mathrm{L}$} & Washout & 0.75 & 0.83 & 0.52 & 0.81 & 0.11 & 0.22 & 0.68 & 0.47 \\
\hline & Dosage & 0.72 & 0.59 & 0.57 & 0.56 & 0.10 & & & \\
\hline \multirow[t]{2}{*}{ Total bilirubin, $\mu \mathrm{mol} / \mathrm{L}$} & Washout & 1.40 & 1.48 & 1.48 & 1.45 & 0.25 & 0.78 & 0.25 & 0.56 \\
\hline & Dosage & 1.17 & 1.11 & 1.06 & 1.17 & 0.24 & & & \\
\hline \multirow[t]{2}{*}{ Total protein, $\mathrm{g} / \mathrm{L}$} & Washout & 77.9 & 77.8 & 72.1 & 82.0 & 3.3 & 0.98 & 0.97 & 0.78 \\
\hline & Dosage & 78.2 & 77.2 & 78.0 & 79.7 & 3.3 & & & \\
\hline \multirow[t]{4}{*}{ Albumin, g/L } & Washout & 31.5 & 30.2 & 30.4 & 32.2 & 1.1 & 0.02 & 0.32 & 0.73 \\
\hline & Dosage 1 & 30.9 & 30.4 & 30.5 & 29.7 & 1.1 & & & \\
\hline & Dosage 2 & 31.7 & 30.4 & 29.6 & 31.2 & 1.1 & & & \\
\hline & Dosage 3 & $32.9^{\mathrm{a}}$ & $30.8^{\mathrm{ab}}$ & $29.1^{\mathrm{b}}$ & $32.0^{\mathrm{ab}}$ & 1.1 & & & \\
\hline \multirow[t]{2}{*}{ Urea, mmol/L } & Washout & 5.06 & 4.46 & 4.58 & 4.65 & 0.51 & 0.59 & 0.64 & 0.96 \\
\hline & Dosage & 5.07 & 4.46 & 3.91 & 4.20 & 0.51 & & & \\
\hline
\end{tabular}

${ }^{\mathrm{a}, \mathrm{b}}$ Means within a row with different superscripts differ $(P<0.05)$.

${ }^{1}$ Values are LSM with SE; $\mathrm{n}=4$ per group.

${ }^{2}$ The initial dosage was doubled twice for $2 \mathrm{wk}$, resulting in a 6 -wk treatment period with 3 dosages (1, 2, 3) followed by a 3 -wk washout period. Samples were collected at wk $0,2,4$, and 6 . Means for dosages 1,2 , and 3 are given when there was no dosage effect and no treatment effect with an individual dosage. The complete data with respect to dosage for all parameters are presented in Supplemental Table S6 (https://doi .org/10.3168/jds.2020-18569).

${ }^{3}$ CTRL $($ control) $=$ coconut oil (Bio-Kokosöl no. 665, Kräuterhaus Sanct Bernhard KG, Bad Ditzenbach, Germany). EFA = linseed oil (Derby Leinöl no. 4026921003087, Derby Spezialfutter GmbH, Münster, Germany) and safflower oil (Gefro Distelöl, Gefro Reformversand Frommlet KG, Memmingen, Germany). CLA = Lutalin (CLA cis-9,trans-11 and trans-10, cis-12; BASF SE, Ludwigshafen, Germany). EFA+CLA = linseed oil (Derby Leinöl no. 4026921003087), safflower oil (Gefro Distelöl), and Lutalin. 
A

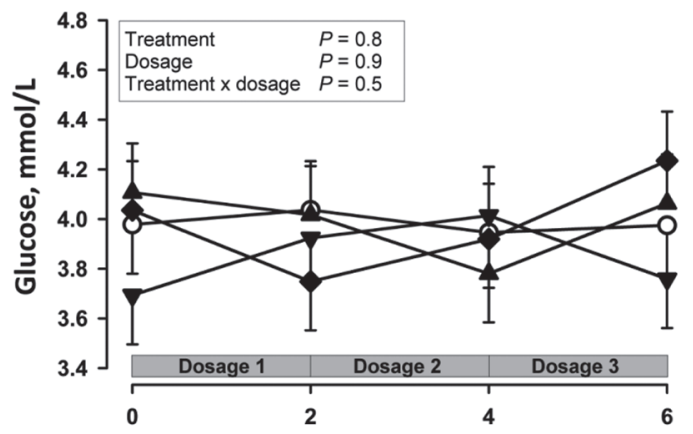

C

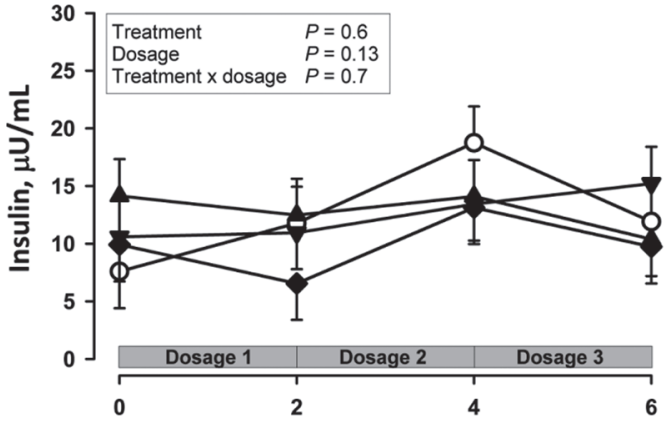

$\mathbf{E}$

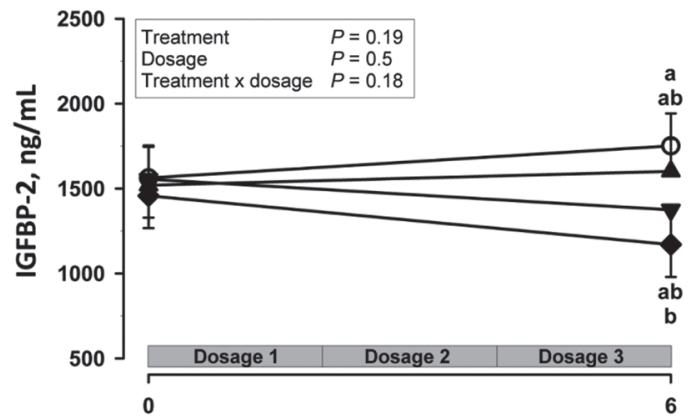

Week of supplementation
B

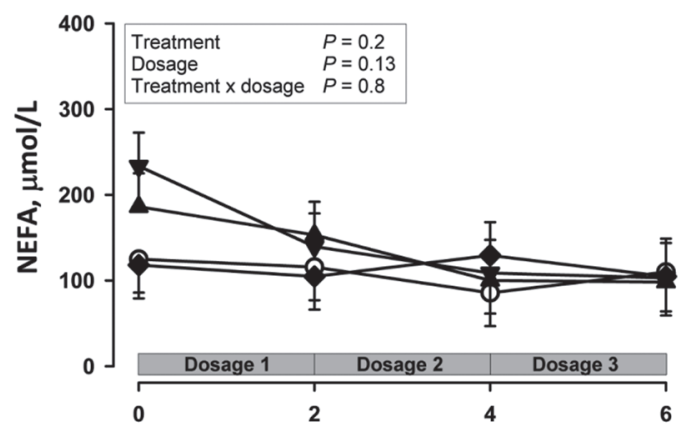

D

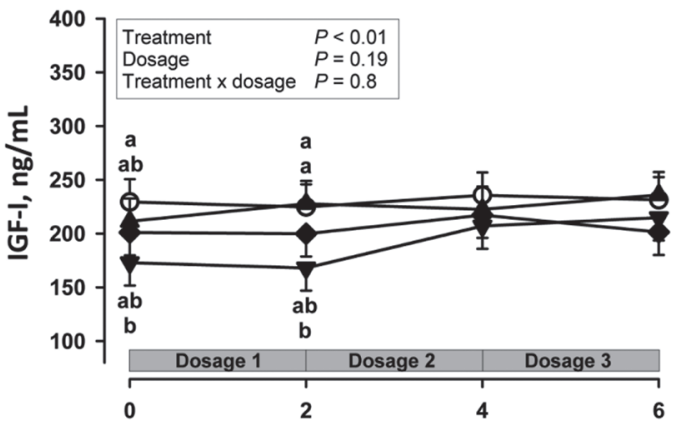

F

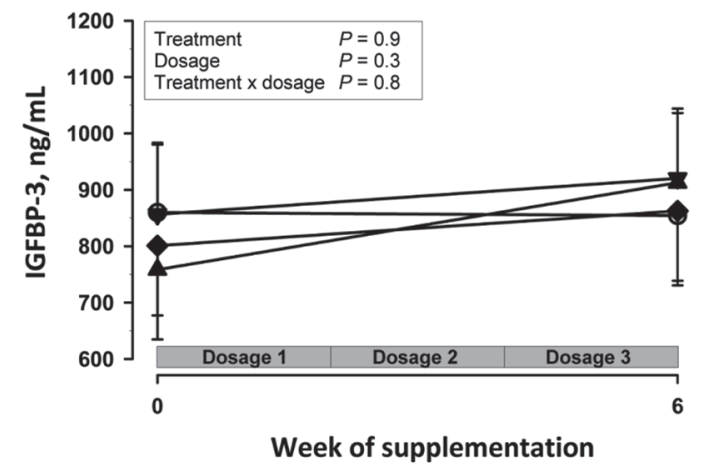

Figure 2. (A) Plasma concentrations of glucose, (B) nonesterified fatty acids (NEFA), (C) insulin, (D) IGF-I, (E) IGFBP-2, and (F) IGFBP-3 in cows fed a corn silage-based diet and abomasally treated with coconut oil ( $\bigcirc$ CTRL), linseed and safflower oils $(\boldsymbol{\Delta}$ EFA), Lutalin $(\boldsymbol{\nabla}$ CLA cis-9,trans-11 and trans-10,cis-12), or ( EFA+CLA at dosages 1, 2, and 3 (wk 2, 4, and 6, respectively). The initial dosage was doubled twice for $2 \mathrm{wk}$, resulting in a 6 -wk treatment period with 3 dosages $(1,2,3)$ followed by a 3 -wk washout period. Values are the LSM \pm SE, $\mathrm{n}=$ 4 per group; means with different letters $(\mathrm{a}, \mathrm{b})$ differ $(P<0.05)$.

such as n-3 and n-6 decreases the plasma cholesterol concentration in humans and other monogastric animals (Jaturasitha et al., 2002; Chan et al., 2003), mainly by reducing LDL-C in blood plasma and affecting HDL-C remodeling and reverse cholesterol transport (Fernandez and West, 2005; Pizzini et al., 2017). Low-density lipoproteins represent approximately $10 \%$ of the total lipoproteins in ruminants; they are the end products of intravascular degradation of VLDL, the principal bovine lipoprotein of intestinal origin (Hocquette and
Bauchart, 1999), and are also involved in cholesterol distribution toward tissues (Palmquist, 1976; Bauchart, 1993). The original protein-rich particles of HDL are synthesized and secreted mainly by the liver and small intestine, and HDL incorporates cholesterol from chylomicron and VLDL. High-density lipoprotein is responsible for reverse cholesterol transport from peripheral cells to the liver and plays a major role in cholesterol ester transport in cattle (Grummer and Carroll, 1988; Bauchart, 1993; Hocquette and Bauchart, 1999). Low- 
density lipoprotein transports most of the cholesterol in the blood plasma of pigs and humans, but HDL is the major plasma lipoprotein in cattle (Grummer and Carroll, 1988). Obviously, ruminants differ in their response of lipoproteins in blood plasma to PUFA treatments from monogastric animals, and further studies are needed to clarify the reason for this difference in response.

The hepatic expression of HMGCS1, which is one of the key enzymes in cholesterol biosynthesis and is upregulated in early lactation (Viturro et al., 2009; Kessler et al., 2014), increased in EFA+CLA in comparison to NO. This might indicate an increase in cholesterol biosynthesis and is consistent with the elevated total cholesterol concentration in blood plasma of EFA+CLA cows. Both endogenously produced and externally supplied cholesterol affect the plasma cholesterol level depending on the supply of FA (Rindsig and Schultz, 1974; Drackley et al., 1992). Because the formation of bile acids represents an important source of cholesterol loss in the liver (Schlegel et al., 2012), the increased supply of PUFA in EFA+CLA cows might have stimulated hepatic cholesterol synthesis to cover the increased requirement of cholesterol for intestinal PUFA absorption.
Sterol element-binding factors are transcription factors that are involved in the regulation of cholesterol biosynthesis and lipid metabolism (Desvergne et al., 2006; Daemen et al., 2013; Kessler et al., 2014). In the present study, the expression of total SREBF1 (SREBF1a and $1 c$ ) in liver tissue tended to be downregulated by both EFA treatments, which is consistent with previous studies that indicated depression of $S R E B F 1$ by PUFA in cell-culture systems (Xu et al., 1999; Ayala-Sumuano et al., 2011) as well as in the livers of mice and rats (Xu et al., 1999; Takeuchi et al., 2010). Even though cholesterol synthesis is predominantly controlled by SREBF2 (Horton et al., 1998), Deckelbaum et al. (2006) also reported a crossover in the activities of SREBF1 and 2. The reduced mRNA abundance of SREBF1 in EFA cows may have caused decreased lipid biosynthesis in the liver after EFA treatment (Desvergne et al., 2006; Daemen et al., 2013), although the plasma concentration of cholesterol increased with EFA treatment. The low mRNA abundance of SREBF1 in EFA cows may have also affected hepatic fatty acid oxidation, as indicated by the trend of low ASCL1 and CPT1A mRNA abundances in EFA-treated cows and desaturation of FA (Loor, 2010). The gene expression of SREBF1 is regulated by insulin and is decreased in transition

Table 3. Effects of abomasal treatments on plasma concentrations of leptin, adiponectin, cortisol, glucagon, IGFBP-4, and the IGFBP-3:IGFBP -2 ratio $^{1}$

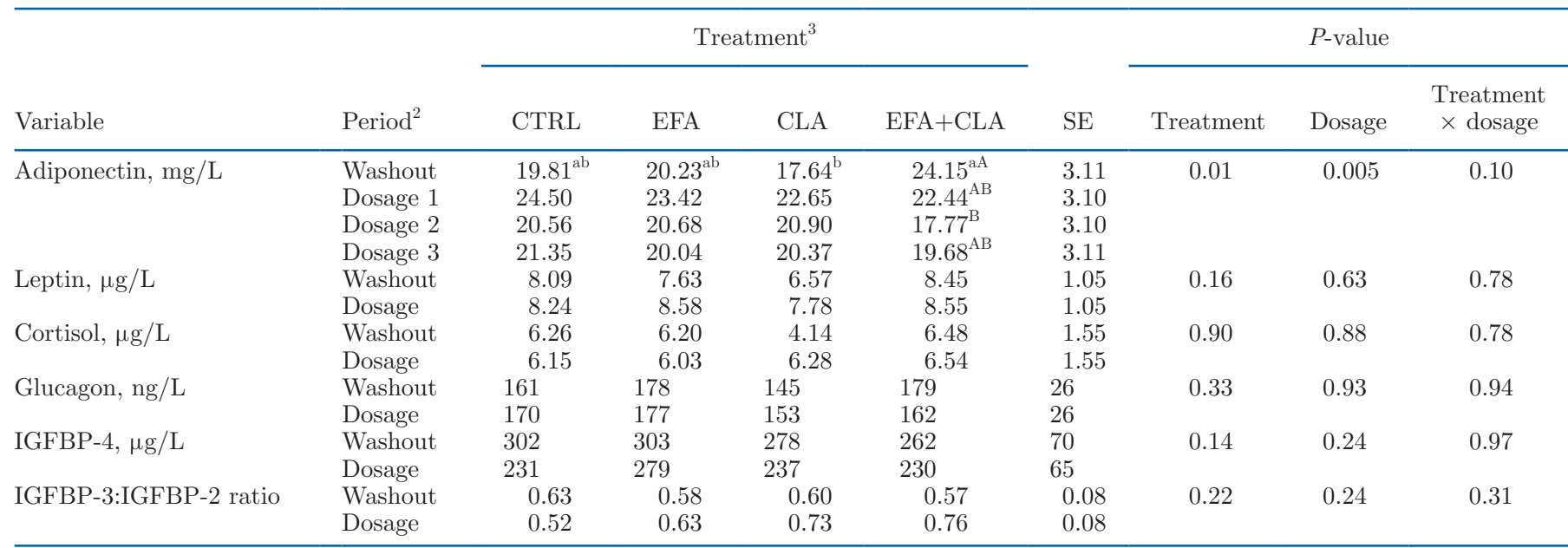

${ }^{\mathrm{a}, \mathrm{b}}$ Means within a row with different superscripts differ $(P<0.05)$.

${ }^{\mathrm{A}, \mathrm{B}}$ Means within a column with different superscripts differ $(P<0.05)$.

${ }^{1}$ Values are LSM with $\mathrm{SE} ; \mathrm{n}=4$ per group.

${ }^{2}$ The initial dosage was doubled twice for $2 \mathrm{wk}$, resulting in a 6 -wk treatment period with 3 dosages $(1,2,3)$ followed by a 3 -wk washout period. Samples were collected at wk 0,2, 4, and 6 (for IGF-binding proteins only at wk 0 and 6 ). Means for dosages 1,2 , and 3 are given when there was no dosage effect and no treatment effect with an individual dosage. The complete data with respect to dosage for all parameters are presented in Supplemental Table S7 (https://doi.org/10.3168/jds.2020-18569).

${ }^{3}$ CTRL $($ control $)=$ coconut oil (Bio-Kokosöl no. 665, Kräuterhaus Sanct Bernhard KG, Bad Ditzenbach, Germany). EFA = linseed oil (Derby Leinöl no. 4026921003087, Derby Spezialfutter GmbH, Münster, Germany) and safflower oil (Gefro Distelöl, Gefro Reformversand Frommlet KG, Memmingen, Germany). CLA = Lutalin (CLA cis-9,trans-11 and trans-10,cis-12; BASF SE, Ludwigshafen, Germany). EFA+CLA = linseed oil (Derby Leinöl no. 4026921003087), safflower oil (Gefro Distelöl), and Lutalin. 
dairy cows with a low insulin status (Desvergne et al., 2006; Loor, 2010; Kessler et al., 2014). Although there was no effect of EFA treatment on the insulin status of the cows herein, the increased availability of PUFA (present study) or NEFA (transition cow; Kessler et al., 2014) stimulated the biosynthesis of lipoproteins for FA transport (Daemen et al., 2013) and simultaneously decreased FA biosynthesis (Kessler et al., 2014).

\section{Effects of FA Supplementation on Systemic and Hepatic Metabolic and Endocrine Traits, Including the Somatotropic Axis}

The FA supplements did not affect traits representing energy metabolism, such as plasma glucose, BHB, and NEFA concentrations. However, in the companion paper (Haubold et al., 2020), we describe a slight effect of the CLA treatment on the energy balance of the cows. Cows in this study were in the mid-lactation stage and were not exposed to a critical metabolic load, but the reduced milk fat release in CLA-treated cows resulted in an improved energy balance in these cows (Haubold et al., 2020).

The improved energy status of CLA-treated cows was best reflected in the plasma concentration of IGFBP-2. Insulin-like growth factor binding protein-2 is one of several binding proteins that bind IGF-I in blood plasma and regulate its availability to the tissue (Jones and Clemmons, 1995). The plasma concentration of IGFBP-2 is regulated by nutrient intake and is elevated in cattle during fasting or reduced feed intake (Thissen et al., 1994; Renaville et al., 2002). The plasma concentration of IGFBP-2 in the present study was significantly lower in EFA+CLA-treated cows and was numerically lower in CLA-treated cows than in CTRL cows at the end of the treatment period. Because there is an inverse relationship between the energy balance and plasma IGFBP-2 concentration in dairy cows (Cohick, 1998),

Table 4. Relative mRNA expression in the liver of dairy cows without supplementation (NO) and with supplementation with coconut oil (CTRL), linseed and safflower oils (EFA), Lutalin (CLA cis-9,trans-11 and trans-10, cis-12), or the combination (EFA+CLA)

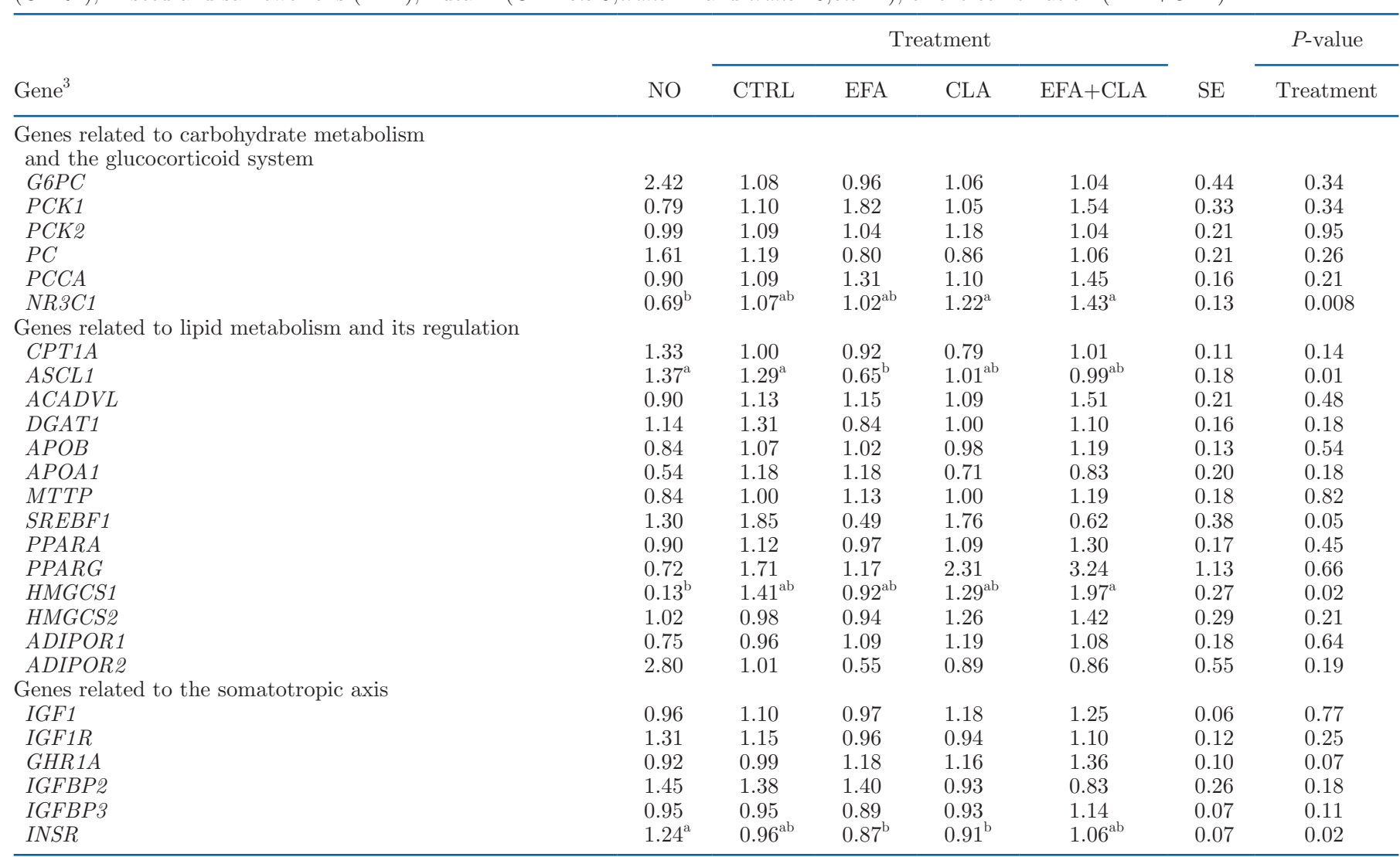

${ }^{\mathrm{a}, \mathrm{b}}$ Means within a row with different superscripts differ $(P<0.05)$.

${ }^{1}$ Cows were investigated in a $4 \times 4$ dose-escalation study and were provided daily supplements of coconut oil (CTRL), linseed and safflower oils (EFA), Lutalin (CLA, cis-9,trans-11 and trans-10,cis-12), and EFA+CLA.

${ }^{2}$ The initial dosage was doubled twice for $2 \mathrm{wk}$, resulting in a 6 -wk treatment period with 3 dosages $(1,2,3)$ followed by a 3 -wk washout period. Samples were collected before the start of the trial (basal sample, no treatment, NO) and after 6 wk of abomasal treatments.

${ }^{3}$ Values are LSM and SE; $\mathrm{n}=4$ per group. 
CLA treatment was probably the main reason for the decrease in plasma IGFBP-2 due to the improvement in the energy status of the cows (Haubold et al., 2020). No other IGFBP measured in blood plasma indicated any treatment effect in the present study.

Interestingly, the plasma IGF-I concentration was higher in CTRL-treated cows than in CLA-treated cows. This finding was inconsistent with the literature, and it is well known that the plasma IGF-I concentration is reduced after feed deprivation or reduced feed intake in cattle (Cohick, 1998; Renaville et al., 2002). The differences in plasma IGF-I concentration in the present study were unexpectedly observed at the beginning of the respective treatment period, which was probably a random effect. In addition, the plasma concentration of IGF-I increased with increasing dosage in CLA cows. Previous studies indicate a stimulatory effect of CLA on the somatotropic axis and a direct relationship between the amount of CLA supplementation (trans-10,cis-12 CLA) and an elevated plasma IGF-I concentration (Castañeda-Gutiérrez et al., 2007; Csillik et al., 2017).

Systemically available IGF-I and its IGFBP are primarily produced in the liver, and IGF-I synthesis as well as some of the IGFBP are regulated by the binding of growth hormone to the hepatic growth hormone receptor (Jones and Clemmons, 1995; Edens and Talamantes, 1998; Le Roith et al., 2001). Hepatic gene expression of IGFBP2 was numerically lower in only CLA- and EFA+CLA-treated cows, and gene expression of $I G F B P 3$ was numerically higher in EFA+CLAtreated cows, but gene expression of GHR1A tended to be highest in EFA+CLA cows. This finding might indicate stimulation of the somatotropic axis due to EFA+CLA treatment, but this was not reflected by the elevated hepatic IGF1 gene expression, although the IGF1 mRNA abundance in the liver was numerically highest in EFA+CLA cows. The gene expression of GHR1A is stimulated in dairy cows by insulin (Butler et al., 2003; Weber et al., 2017). However, FA treatments did not affect the plasma insulin concentration in the present study. In addition, there was a decrease in hepatic INSR mRNA abundance in EFA and CLA cows after the end of the treatment period. Therefore, the treatment effects of GHR1A gene expression in the present study might not be explained by the insulin status in these cows. This assessment was further confirmed by the plasma adiponectin concentration in the present study. Adiponectin supports insulin sensitivity (Berg et al., 2001; Yadav et al., 2013); the adiponectin concentration was highest in EFA+CLA-treated cows after the washout and before the beginning of the treatment, and decreased during the treatment period. Interestingly, the $N R 3 C 1 \mathrm{mRNA}$ abundance was highest in both CLA-treated groups. It is known that glucocorticoids can stimulate the hepatic growth hormone receptor, at least in calves (Sauter et al., 2003), and affect IGFBP (Renaville et al., 2002). However, in the present study, the plasma cortisol concentration was not affected by FA treatments. Therefore, further research is necessary to investigate the effects on the glucocorticoid system induced by FA treatment, and their consequences for the somatotropic axis in dairy cows.

Plasma albumin and urea concentrations tended to be lower in CLA than in CTRL in the present study. In our companion paper (Haubold et al., 2020), we reported a decrease in milk protein and milk urea concentrations in CLA and EFA+CLA cows. Although we cannot rule out the possibility that the influence on protein metabolism may be partly due to the relatively low protein intake, earlier studies have discussed a higher body protein accretion and nitrogen retention in cows treated with CLA (Shingfield et al., 2004; von Soosten et al., 2012). The possible effect of CLA on protein metabolism might be mediated by the somatotropic axis. Stimulation of the somatotropic axis leads to increased $\mathrm{N}$ retention and reduced plasma urea concentration (Clemmons and Underwood, 1991; Renaville et al., 2002). Therefore, the stimulatory effect on $\mathrm{N}$ retention due to CLA treatment might be facilitated in part by the somatotropic axis (Park et al., 1997; Schiavon et al., 2010; Shokryzadan et al., 2017).

\section{CONCLUSIONS}

Supplementation with EFA and CLA affected cholesterol biosynthesis, which led to increased hepatic expression of HMGCS1 and elevated cholesterol plasma levels, and influenced plasma lipoproteins. Some of the effects were most evident in the combined EFA and CLA treatment. Furthermore, our results confirm that EFA treatment, with or without CLA, leads to downregulation of the expression of $S R E B F 1$ in the liver, indicating an influence of EFA on the regulation of hepatic FA and cholesterol metabolism. CLA treatment, especially in combination with EFA, had beneficial effects on the regulation of the somatotropic axis. These effects underline the improved energetic status in CLAtreated cows and may partly explain the effects of CLA on body protein metabolism.

\section{ACKNOWLEDGMENTS}

We thank Christa Fiedler and Jeannine Gruse for experimental support and Claudia Reiko, Birgit Mielenz, and Heike Pröhl (Nutritional Physiology, FBN Dummerstorf, Germany) for analytical assistance. Addition- 
ally, we thank the Animal Experimental Unit of the FBN for providing excellent technical assistance. We further acknowledge Dr. Christine Höflich (Ligandis UG, Gülzow, Germany) for quantification of IGFBP and the Cattle Breeding Organization of MecklenburgWest Pomerania (Rinderallianz, Woldegk, Germany) for providing the assortment of cows. The study was supported by BASF, Ludwigshafen, Germany. The authors declare that there are no conflicts of interest.

\section{REFERENCES}

Ashes, J. R., R. W. Burley, J. B. Davenport, and G. S. Sidhu. 1982. Effects of dietary supplements of protected lipids on the concentration and transport of beta-carotene and cholesterol in bovine blood and milk: unusual chromatographic behaviour of the highdensity lipoprotein with high levels of beta-carotene. J. Dairy Res. 49:39-49. https://doi.org/10.1017/S0022029900022111.

Ayala-Sumuano, J. T., C. Velez-delValle, A. Beltran-Langarica, M. Marsch-Moreno, J. Cerbon-Solorzano, and W. Kuri-Harcuch. 2011. Srebfla is a key regulator of transcriptional control for adipogenesis. Sci. Rep. 1:178.

Bauchart, D. 1993. Lipid absorption and transport in ruminants. J. Dairy Sci. 76:3864-3881. https://doi.org/10.3168/jds.S0022 -0302(93)77728-0.

Bauman, D., L. Baumgard, B. Corl, and J. Griinari. 2000. Biosynthesis of conjugated linoleic acid in ruminants. J. Anim. Sci. $77(\mathrm{E}-$ Suppl):1-15. https://doi.org/10.2527/jas2000.77E-Suppl1f.

Bauman, D. E. 2000. Regulation of nutrient partitioning during lactation: Homeostasis and homeorhesis revisited. Pages 311-328 in Ruminant Physiology: Digestion, Metabolism, Growth and Reproduction. P. B. Cronje, ed. CAB International, Wallingford, UK.

Bauman, D. E., K. J. Harvatine, and A. L. Lock. 2011. Nutrigenomics, rumen-derived bioactive fatty acids, and the regulation of milk fat synthesis. Annu. Rev. Nutr. 31:299-319. https://doi.org/10.1146/ annurev.nutr.012809.104648.

Benninghoff, J., K. Metzger-Petersen, A. H. Tröscher, and K. H. Südekum. 2015. Does trans-10, cis-12 conjugated linoleic acid affect the intermediary glucose and energy expenditure of dairy cows due to repartitioning of milk component synthesis? J. Dairy Res. 82:407-415.

Benson, J. A., C. K. Reynolds, D. J. Humphries, S. M. Rutter, and D. E. Beever. 2001. Effects of abomasal infusion of long-chain fatty acids on intake, feeding behavior and milk production in dairy cows. J. Dairy Sci. 84:1182-1191. https://doi.org/10.3168/jds .S0022-0302(01)74579-1.

Berg, A. H., T. P. Combs, X. Du, M. Brownlee, and P. E. Scherer. 2001. The adipocyte-secreted protein Acrp30 enhances hepatic insulin action. Nat. Med. 7:947-953. https://doi.org/10.1038/90992.

Bitman, J., L. P. Dryden, H. K. Goering, T. R. Wrenn, R. A. Yoncoskie, and L. F. Edmondso. 1973. Efficiency of transfer of polyunsaturated fats into milk. J. Am. Oil Chem. Soc. 50:93-98. https:// doi.org/10.1007/BF02671110.

Butler, S. T., A. L. Marr, S. H. Pelton, R. P. Radcliff, M. C. Lucy, and W. R. Butler. 2003. Insulin restores GH responsiveness during lactation-induced negative energy balance in dairy cattle: Effects on expression of IGF-I and GH receptor 1A. J. Endocrinol. 176:205-217. https://doi.org/10.1677/joe.0.1760205.

Castañeda-Gutiérrez, E., B. C. Benefield, M. J. de Veth, N. R. Santos, R. O. Gilbert, W. R. Butler, and D. E. Bauman. 2007. Evaluation of the mechanism of action of conjugated linoleic acid isomers on reproduction in dairy cows. J. Dairy Sci. 90:4253-4264. https://doi .org/10.3168/jds.2007-0117.

Chan, D. C., G. F. Watts, T. A. Mori, P. H. Barrett, T. G. Redgrave, and L. J. Beilin. 2003. Randomized controlled trial of the effect of n-3 fatty acid supplementation on the metabolism of apolipoprotein B-100 and chylomicron remnants in men with visceral obesity.
Am. J. Clin. Nutr. 77:300-307. https://doi.org/10.1093/ajcn/77 .2 .300 .

Chilliard, Y., A. Ferlay, and M. Doreau. 2001. Effect of different types of forages, animal fat or marine oils in cow's diet on milk fat secretion and composition, especially conjugated linoleic acid (CLA) and polyunsaturated fatty acids. Livest. Prod. Sci. 70:31-48. https: //doi.org/10.1016/S0301-6226(01)00196-8.

Clemmons, D. R., and L. E. Underwood. 1991. Nutritional regulation of IGF-I and IGF binding proteins. Annu. Rev. Nutr. 11:393-412. https://doi.org/10.1146/annurev.nu.11.070191.002141.

Cohick, W. S. 1998. Role of the insulin-like growth factors and their binding proteins in lactation. J. Dairy Sci. 81:1769-1777. https:// doi.org/10.3168/jds.S0022-0302(98)75746-7.

Csillik, Z., V. Faigl, M. Keresztes, E. Galamb, H. M. Hammon, A. Troscher, H. Febel, M. Kulcsar, F. Husveth, G. Huszenicza, and W. R. Butler. 2017. Effect of pre- and postpartum supplementation with lipid-encapsulated conjugated linoleic acid on reproductive performance and the growth hormone-insulin-like growth factor-I axis in multiparous high-producing dairy cows. J. Dairy Sci. 100:5888-5898. https://doi.org/10.3168/jds.2016-12124.

Daemen, S., M. Kutmon, and C. T. Evelo. 2013. A pathway approach to investigate the function and regulation of SREBPs. Genes Nutr. 8:289-300. https://doi.org/10.1007/s12263-013-0342-x.

Daxenberger, A., H. Sauerwein, and B. H. Breier. 1998. Increased milk levels of insulin-like growth factor 1 (IGF-1) for the identification of bovine somatotropin (bST) treated cows. Analyst 123:24292435. https://doi.org/10.1039/a804923h.

Deckelbaum, R. J., T. S. Worgall, and T. Seo. 2006. n-3 fatty acids and gene expression. Am. J. Clin. Nutr. 83:1520S-1525S. https:// doi.org/10.1093/ajen/83.6.1520S.

Desvergne, B., L. Michalik, and W. Wahli. 2006. Transcriptional regulation of metabolism. Physiol. Rev. 86:465-514. https://doi.org/10 .1152 /physrev.00025.2005.

Drackley, J. K., T. H. Klusmeyer, A. M. Trusk, and J. H. Clark. 1992. Infusion of long-chain fatty acids varying in saturation and chain length into the abomasum of lactating dairy cows. J. Dairy Sci. 75:1517-1526. https://doi.org/10.3168/jds.S0022-0302(92)77908 $-9$.

Edens, A., and F. Talamantes. 1998. Alternative processing of growth hormone receptor transcripts. Endocr. Rev. 19:559-582.

Ferlay, A., B. Martin, P. Pradel, J. B. Coulon, and Y. Chilliard. 2006. Influence of grass-based diets on milk fatty acid composition and milk lipolytic system in Tarentaise and Montbeliarde cow breeds. J. Dairy Sci. 89:4026-4041. https://doi.org/10.3168/jds.S0022 $-0302(06) 72446-8$

Fernandez, M. L., and K. L. West. 2005. Mechanisms by which dietary fatty acids modulate plasma lipids. J. Nutr. 135:2075-2078. https: //doi.org/10.1093/jn/135.9.2075.

Frieten, D., C. Gerbert, C. Koch, G. Dusel, K. Eder, A. Hoeflich, B. Mielenz, and H. M. Hammon. 2018. Influence of ad libitum milk replacer feeding and butyrate supplementation on the systemic and hepatic insulin-like growth factor I and its binding proteins in Holstein calves. J. Dairy Sci. 101:1661-1672. https://doi.org/10 .3168/jds.2017-13603.

GfE (German Society of Nutrition Physiology). 2001. Empfehlungen zur Energie- und Nährstoffversorgung der Milchkühe und Aufzuchtrinder [Recommended energy and nutrient supply for dairy cows and heifers]. Ausschuss für Bedarfsnormen der Gesellschaft für Ernährungsphysiologie No. 8. DLG Verlag, Frankfurt am Main, Germany.

GfE (German Society of Nutrition Physiology). 2008. New equations for predicting metabolisable energy of grass and maize products for ruminants. Mitteilung des Ausschusses für Bedarfsnormen der Gesellschaft für Ernährungsphysiologie. Proc. Soc. Nutr. Physiol. 17:191-198.

Greco, L. F., J. N. Neto, A. Pedrico, R. Ferrazza, F. Lima, R. Bisinotto, N. Martinez, M. Garcia, E. Ribeiro, G. Gomes, J. H. Shin, M. A. Ballou, W. W. Thatcher, C. R. Staples, and J. E. P. Santos. 2015. Effects of altering the ratio of dietary n-6 to n-3 fatty acids on performance and inflammatory responses to a lipopolysaccha- 
ride challenge in lactating Holstein cows. J. Dairy Sci. 98:602-617. https://doi.org/10.3168/jds.2014-8805.

Grummer, R. R., and D. J. Carroll. 1988. A review of lipoprotein cholesterol metabolism: Importance to ovarian function. J. Anim. Sci. 66:3160-3173. https://doi.org/10.2527/jas1988.66123160x.

Hammon, H. M., G. Stürmer, F. Schneider, A. Tuchscherer, H. Blum, T. Engelhard, A. Genzel, R. Staufenbiel, and W. Kanitz. 2009. Performance and metabolic and endocrine changes with emphasis on glucose metabolism in high-yielding dairy cows with high and low fat content in liver after calving. J. Dairy Sci. 92:1554-1566. https://doi.org/10.3168/jds.2008-1634.

Haubold, S., C. Kröger-Koch, A. Starke, A. Tuchscherer, A. Troscher, H. Kienberger, M. Rychlik, U. Bernabucci, E. Trevisi, and H. M. Hammon. 2020. Effects of abomasal infusion of essential fatty acids and conjugated linoleic acid on performance and fatty acid, antioxidative, and inflammatory status in dairy cows. J. Dairy Sci. 103:972-991. https://doi.org/10.3168/jds.2019-17135.

Hocquette, J. F., and D. Bauchart. 1999. Intestinal absorption, blood transport and hepatic and muscle metabolism of fatty acids in preruminant and ruminant animals. Reprod. Nutr. Dev. 39:27-48. https://doi.org/10.1051/rnd:19990102.

Horton, J. D., I. Shimomura, M. S. Brown, R. E. Hammer, J. L. Goldstein, and H. Shimano. 1998. Activation of cholesterol synthesis in preference to fatty acid synthesis in liver and adipose tissue of transgenic mice overproducing sterol regulatory element-binding protein-2. J. Clin. Invest. 101:2331-2339. https://doi.org/10.1172/ JCI2961.

Hötger, K., H. M. Hammon, C. Weber, S. Gors, A. Troscher, R. M. Bruckmaier, and C. C. Metges. 2013. Supplementation of conjugated linoleic acid in dairy cows reduces endogenous glucose production during early lactation. J. Dairy Sci. 96:2258-2270. https:/ /doi.org/10.3168/jds.2012-6127.

Jaturasitha, S., Y. Wudthithumkanaporn, P. Rurksasen, and M. Kreuzer. 2002. Enrichment of pork with omega-3 fatty acids by tuna oil supplements: Effects on performance as well as sensory, nutritional and processing properties of pork. Asian-Australas. J. Anim. Sci. 15:1622-1633

Jones, J. I., and D. R. Clemmons. 1995. Insulin-like growth factors and their binding proteins: biological actions. Endocr. Rev. 16:3-34. https://doi.org/10.1210/edrv-16-1-3.

Kelly, M. L., E. S. Kolver, D. E. Bauman, M. E. Van Amburgh, and L. D. Muller. 1998. Effect of intake of pasture on concentrations of conjugated linoleic acid in milk of lactating cows. J. Dairy Sci. 81:1630-1636. https://doi.org/10.3168/jds.S0022-0302(98)75730 $-3$.

Kesser, J., M. Hill, J. F. Heinz, C. Koch, J. Rehage, J. SteinhoffWagner, H. M. Hammon, B. Mielenz, H. Sauerwein, and H. Sadri. 2015. The rapid increase of circulating adiponectin in neonatal calves depends on colostrum intake. J. Dairy Sci. 98:7044-7051. https://doi.org/10.3168/jds.2015-9726.

Kessler, E. C., J. J. Gross, R. M. Bruckmaier, and C. Albrecht. 2014. Cholesterol metabolism, transport, and hepatic regulation in dairy cows during transition and early lactation. J. Dairy Sci. 97:54815490. https://doi.org/10.3168/jds.2014-7926.

Khan, N. A., P. Yu, M. Ali, J. W. Cone, and W. H. Hendriks. 2015. Nutritive value of maize silage in relation to dairy cow performance and milk quality. J. Sci. Food Agric. 95:238-252. https:// doi.org/10.1002/jsfa.6703.

Khiaosa-Ard, R., M. Kreuzer, and F. Leiber. 2015. Apparent recovery of $\mathrm{C} 18$ polyunsaturated fatty acids from feed in cow milk: A meta-analysis of the importance of dietary fatty acids and feeding regimens in diets without fat supplementation. J. Dairy Sci. 98:6399-6414. https://doi.org/10.3168/jds.2015-9459.

Laeger, T., E. Wirthgen, M. Piechotta, F. Metzger, C. C. Metges, B. Kuhla, and A. Hoeflich. 2014. Effects of parturition and feed restriction on concentrations and distribution of the insulin-like growth factor-binding proteins in plasma and cerebrospinal fluid of dairy cows. J. Dairy Sci. 97:2876-2885. https://doi.org/10.3168/ jds.2013-7671.

Lahlou, M. N., R. Kanneganti, L. J. Massingill, G. A. Broderick, Y. Park, M. W. Pariza, J. D. Ferguson, and Z. Wu. 2014. Grazing increases the concentration of CLA in dairy cow milk. Animal 8:1191-1200. https://doi.org/10.1017/S1751731114000998.

Lands, B. 2014. Historical perspectives on the impact of n-3 and n-6 nutrients on health. Prog. Lipid Res. 55:17-29. https://doi.org/10 .1016/j.plipres.2014.04.002.

Le Roith, D., C. Bondy, S. Yakar, J.-L. Liu, and A. Butler. 2001. The somatomedin hypothesis: 2001. Endocr. Rev. 22:53-74. https://doi .org/10.1210/edrv.22.1.0419.

Loor, J. J. 2010. Genomics of metabolic adaptations in the peripartal cow. Animal 4:1110-1139. https://doi.org/10.1017/ S1751731110000960.

Mattos, R., C. R. Staples, and W. W. Thatcher. 2000. Effects of dietary fatty acids on reproduction in ruminants. Rev. Reprod. 5:3845. https://doi.org/10.1530/ror.0.0050038.

Mensink, R. P., P. L. Zock, A. D. Kester, and M. B. Katan. 2003 Effects of dietary fatty acids and carbohydrates on the ratio of serum total to HDL cholesterol and on serum lipids and apolipoproteins: A meta-analysis of 60 controlled trials. Am. J. Clin. Nutr. 77:1146-1155. https://doi.org/10.1093/ajcn/77.5.1146.

Mielenz, M., B. Mielenz, S. P. Singh, C. Kopp, J. Heinz, S. Haussler, and H. Sauerwein. 2013. Development, validation, and pilot application of a semiquantitative Western blot analysis and an ELISA for bovine adiponectin. Domest. Anim. Endocrinol. 44:121-130. https://doi.org/10.1016/j.domaniend.2012.10.004.

Moallem, U. 2018. Invited review: Roles of dietary n-3 fatty acids in performance, milk fat composition, and reproductive and immune systems in dairy cattle. J. Dairy Sci. 101:8641-8661. https://doi .org/10.3168/jds.2018-14772.

Nagao, K., and T. Yanagita. 2005. Conjugated fatty acids in food and their health benefits. J. Biosci. Bioeng. 100:152-157. https://doi .org/10.1263/jbb.100.152.

Nicolosi, R. J. 1997. Dietary fat saturation effects on low-density-lipoprotein concentrations and metabolism in various animal models Am. J. Clin. Nutr. 65:1617S-1627S. https://doi.org/10.1093/ajcn/ 65.5.1617S.

Palmquist, D. L. 1976. A kinetic concept of lipid transport in ruminants - A Review. J. Dairy Sci. 59:355-363. https://doi.org/10 .3168/jds.S0022-0302(76)84212-9.

Palmquist, D. L. 2010. Essential fatty acids in ruminant diets. Pages 127-141 in Proc. 21st Annual Ruminant Nutrition Symposium, Gainesville, FL. Institute of Food and Agricultural Sciences, University of Florida, Gainesville.

Park, Y., K. J. Albright, W. Liu, J. M. Storkson, M. E. Cook, and M. W. Pariza. 1997. Effect of conjugated linoleic acid on body composition in mice. Lipids 32:853-858. https://doi.org/10.1007/ s11745-997-0109-x.

Pegolo, S., A. Cecchinato, N. Mach, M. Babbucci, M. Pauletto, L. Bargelloni, S. Schiavon, and G. Bittante. 2016. Transcriptomic changes in liver of young bulls caused by diets low in mineral and protein contents and supplemented with n-3 fatty acids and conjugated linoleic acid. PLoS One 11:e0167747. https://doi.org/10 .1371/journal.pone.0167747.

Pires, J. A., J. B. Pescara, A. E. Brickner, N. Silva del Rio, A. P. Cunha, and R. R. Grummer. 2008. Effects of abomasal infusion of linseed oil on responses to glucose and insulin in Holstein cows. J. Dairy Sci. 91:1378-1390. https://doi.org/10.3168/jds.2007-0714.

Pizzini, A., L. Lunger, E. Demetz, R. Hilbe, G. Weiss, C. Ebenbichler, and I. Tancevski. 2017. The role of omega-3 fatty acids in reverse cholesterol transport: A review. Nutrients 9:1099. https://doi.org/ 10.3390/nu9101099.

Renaville, R., M. Hammadi, and D. Portetelle. 2002. Role of the somatotropic axis in the mammalian metabolism. Domest. Anim. Endocrinol. 23:351-360. https://doi.org/10.1016/S0739 -7240(02)00170-4

Rindsig, R. B., and L. H. Schultz. 1974. Effects of abomasal infusions of safflower oil or elaidic acid on blood lipids and milk fat in dairy cows. J. Dairy Sci. 57:1459-1466. https://doi.org/10.3168/ jds.S0022-0302(74)85089-7.

Ruijter, J. M., M. W. Pfaffl, S. Zhao, A. N. Spiess, G. Boggy, J. Blom, R. G. Rutledge, D. Sisti, A. Lievens, K. De Preter, S. Derveaux, J. Hellemans, and J. Vandesompele. 2013. Evaluation of qPCR curve 
analysis methods for reliable biomarker discovery: Bias, resolution, precision, and implications. Methods 59:32-46. https://doi.org/10 .1016/j.ymeth.2012.08.011.

Saremi, B., H. Sauerwein, S. Danicke, and M. Mielenz. 2012. Technical note: Identification of reference genes for gene expression studies in different bovine tissues focusing on different fat depots. J. Dairy Sci. 95:3131-3138. https://doi.org/10.3168/jds.2011-4803.

Sauerwein, H., U. Heintges, A. Hennies, T. Selhorst, and A. Daxenberger. 2004. Growth hormone induced alterations of leptin serum concentrations in dairy cows as measured by a novel enzyme immunoassay. Livest. Prod. Sci. 87:189-195. https://doi.org/10 .1016/j.livprodsci.2003.08.001.

Sauter, S. N., E. Ontsouka, B. Roffler, Y. Zbinden, C. Philipona, M. Pfaffl, B. H. Breier, J. W. Blum, and H. M. Hammon. 2003. Effects of dexamethasone and colostrum intake on the somatotropic axis in neonatal calves. Am. J. Physiol. Endocrinol. Metab. 285:E252E261. https://doi.org/10.1152/ajpendo.00557.2002.

Schiavon, S., F. Tagliapietra, M. Dal Maso, L. Bailoni, and G. Bittante. 2010. Effects of low-protein diets and rumen-protected conjugated linoleic acid on production and carcass traits of growing double-muscled Piemontese bulls. J. Anim. Sci. 88:3372-3383. https://doi.org/10.2527/jas.2009-2558.

Schlegel, G., R. Ringseis, J. Keller, F. J. Schwarz, and K. Eder. 2012. Changes in the expression of hepatic genes involved in cholesterol homeostasis in dairy cows in the transition period and at different stages of lactation. J. Dairy Sci. 95:3826-3836. https://doi.org/10 $.3168 /$ jds.2011-5221.

Scislowski, V., D. Durand, D. Gruffat, and D. Bauchart. 2004. Dietary linoleic acid-induced hypercholesterolemia and accumulation of very light HDL in steers. Lipids 39:125-133. https://doi.org/10 $.1007 / \mathrm{s} 11745-004-1210-\mathrm{x}$

Shingfield, K., D. Beever, C. Reynolds, S. Gulati, D. Humphries, B. Lupoli, G. Hervas, and M. Griinari. 2004. Effect of rumen protected conjugated linoleic acid on energy metabolism of dairy cows during early to mid-lactation. J. Anim. Sci. 82(Suppl. 1):307.

Shingfield, K. J., L. Bernard, C. Leroux, and Y. Chilliard. 2010. Role of trans fatty acids in the nutritional regulation of mammary lipogenesis in ruminants. Animal 4:1140-1166. https://doi.org/10 $.1017 /$ S1751731110000510.

Shokryzadan, P., M. A. Rajion, G. Y. Meng, L. J. Boo, M. Ebrahimi, M. Royan, M. Sahebi, P. Azizi, R. Abiri, and M. F. Jahromi. 2017. Conjugated linoleic acid: A potent fatty acid linked to animal and human health. Crit. Rev. Food Sci. Nutr. 57:2737-2748. https:// doi.org/10.1080/10408398.2015.1060190.

Silvestre, F. T., T. S. M. Carvalho, N. Francisco, J. Santos, C. Staples, T. Jenkins, and W. Thatcher. 2011. Effects of differential supplementation of fatty acids during the peripartum and breeding periods of Holstein cows: I. Uterine and metabolic responses, reproduction, and lactation. J. Dairy Sci. 94:189-204. https://doi .org/10.3168/jds.2010-3370

Simopoulos, A. P. 2002. The importance of the ratio of omega-6/ omega-3 essential fatty acids. Biomed. Pharmacother. 56:365-379. https://doi.org/10.1016/S0753-3322(02)00253-6.

Sordillo, L. M., G. A. Contreras, and S. L. Aitken. 2009. Metabolic factors affecting the inflammatory response of periparturient dairy cows. Anim. Health Res. Rev. 10:53-63. https://doi.org/10.1017/ S1466252309990016.

Spector, A. A., and H.-Y. Kim. 2015. Discovery of essential fatty acids. J. Lipid Res. 56:11-21. https://doi.org/10.1194/jlr.R055095.

Takeuchi, Y., N. Yahagi, Y. Izumida, M. Nishi, M. Kubota, Y. Teraoka, T. Yamamoto, T. Matsuzaka, Y. Nakagawa, M. Sekiya, Y. Iizuka, K. Ohashi, J. Osuga, T. Gotoda, S. Ishibashi, K. Itaka, K.
Kataoka, R. Nagai, N. Yamada, T. Kadowaki, and H. Shimano. 2010. Polyunsaturated fatty acids selectively suppress sterol regulatory element-binding protein-1 through proteolytic processing and autoloop regulatory circuit. J. Biol. Chem. 285:11681-11691. https://doi.org/10.1074/jbc.M109.096107.

Thissen, J. P., J. M. Ketelslegers, and L. E. Underwood. 1994. Nutritional regulation of the insulin-like growth factors. Endocr. Rev. 15:80-101. https://doi.org/10.1210/edrv-15-1-80.

Vargas-Bello-Pérez, E., G. Iniguez-Gonzalez, N. Cancino-Padilla, J. J. Loor, and P. C. Garnsworthy. 2016. Effect of dietary vegetable oils on the fatty acid profile of plasma lipoproteins in dairy cows. Arch. Anim. Nutr. 70:322-332. https://doi.org/10.1080/1745039X .2016 .1182305 .

Viturro, E., M. Koenning, A. Kroemer, G. Schlamberger, S. Wiedemann, M. Kaske, and H. H. D. Meyer. 2009. Cholesterol synthesis in the lactating cow: Induced expression of candidate genes. J. Steroid Biochem. Mol. Biol. 115:62-67. https://doi.org/10.1016/ j.jsbmb.2009.02.011.

von Soosten, D., U. Meyer, M. Piechotta, G. Flachowsky, and S. Danicke. 2012. Effect of conjugated linoleic acid supplementation on body composition, body fat mobilization, protein accretion, and energy utilization in early lactation dairy cows. J. Dairy Sci. 95:1222-1239. https://doi.org/10.3168/jds.2011-4548.

Wathes, D. C., D. R. E. Abayasekara, and R. J. Aitken. 2007. Polyunsaturated fatty acids in male and female reproduction. Biol. Reprod. 77:190-201. https://doi.org/10.1095/biolreprod.107.060558.

Weber, C., C. Hametner, A. Tuchscherer, B. Losand, E. Kanitz, W Otten, S. P. Singh, R. M. Bruckmaier, F. Becker, W. Kanitz, and H. M. Hammon. 2013. Variation in fat mobilization during early lactation differently affects feed intake, body condition, and lipid and glucose metabolism in high-yielding dairy cows. J. Dairy Sci. 96:165-180. https://doi.org/10.3168/jds.2012-5574.

Weber, C., C. Schäff, U. Kautzsch, S. Börner, S. Erdmann, R. Bruckmaier, M. Röntgen, B. Kuhla, and H. Hammon. 2017. Variable liver fat concentration as a proxy for body fat mobilization postpartum has minor effects on insulin-induced changes in hepatic gene expression related to energy metabolism in dairy cows. J. Dairy Sci. 100:1507-1520. https://doi.org/10.3168/jds.2016-11808.

Wirthgen, E., C. Hoflich, M. Spitschak, C. Helmer, B. Brand, J. Langbein, F. Metzger, and A. Hoeflich. 2016. Quantitative Western ligand blotting reveals common patterns and differential features of IGFBP-fingerprints in domestic ruminant breeds and species. Growth Horm. IGF Res. 26:42-49. https://doi.org/10.1016/j.ghir 2015.11.001.

Xu, J., M. T. Nakamura, H. P. Cho, and S. D. Clarke. 1999. Sterol regulatory element binding protein-1 expression is suppressed by dietary polyunsaturated fatty acids. A mechanism for the coordinate suppression of lipogenic genes by polyunsaturated fats. J. Biol. Chem. 274:23577-23583. https://doi.org/10.1074/jbc.274.33 .23577 .

Yadav, A., M. A. Kataria, V. Saini, and A. Yadav. 2013. Role of leptin and adiponectin in insulin resistance. Clin. Chim. Acta 417:80-84. https://doi.org/10.1016/j.cca.2012.12.007.

\section{ORCIDS}

A. Tröscher (ㄴ) https://orcid.org/0000-0002-4198-4427

H. Sauerwein (®) https://orcid.org/0000-0002-6905-4053

H. M. Hammon 주 https://orcid.org/0000-0001-8698-1257 